\title{
Traditional Use of Wild Medicinal Plants By The Folklore of Garhwal Himalaya: A Case Study From Jaiharikhal Block in Pauri Garhwal, Uttarakhand
}

\author{
Pratibha Baluni $^{1} \bullet$ Suniti Kumar Kuriyal ${ }^{1} \bullet$ Kusum Dobriyal $^{2 *}$ \\ ${ }^{1}$ Department of Botany, S. D. M. Govt. P. G. College Doiwala, Deharadun-248001, Uttarakhand, India. \\ ${ }^{2}$ Department of Sanskrit, H. N. B. G. University (A Central University), Campus Pauri-246001, Pauri Garhwal, \\ Uttarakhand, India. \\ *Corresponding author mail: kusumdobriya162@rediffmail.com
}

Received: 19.04.2021; Revised: 19.05.2021; Accepted: 29.05.2021

CSociety for Himalayan Action Research and Development

\begin{abstract}
Uttarakhand Himalaya is a treasure of wild medicinal plants which are traditionally used by the folklore since ancient times when there were no medical facility by and large. This knowledge was initially restricted to some vaidyas in the region but with the passage of time it was inseminated to others specially the credit goes to researchers at various level who ventured in to this knowledge and any how brought it in the form of literature. This contribution is also an attempt by the authors to gather information from rural folk of Jaiharikhal block in District Pauri Garhwal and to present it before scientific community. The information was collected using combined approach of observation, discussion with common habitants and experts, and was further checked for an accuracy using the available literature. A total of 46 Wild-Edible medicinal plants were noted belonging to 34 families and 41 genus. Different plant parts, such as wood oil, resin, latex, roots, root bark, tubers, Rhizomes, stems, bark, leaves, flowers, seeds, hairs on pods, Bulb, fruiting body, fruits and whole plant etc were used by the native communities for the treatment of various ailments.
\end{abstract}

Keyword: Wild Medicinal Flora $\bullet$ Ancient Literature $\bullet$ Traditional Uses $\bullet$ Folklore $\bullet$ Jaiharikhal

\section{Introduction}

India is one of the countries in the world having mega biodiversity with the presence of over 45000 different plants species. Of these, about 15000-20000 plants have great curative relevance. However, three-quarters of plant species are used for their medicinal values by traditional communities (Sharma, 2004). The inhabitants of the Himalayan region across the world have a close relationship with nature. Their life course is fully dependent on forests for fodder, timber, fruits, food, and medicinal plants for their healthcare management. The folklore of the Himalayan region is quite rich in traditional knowledge about the type and use of medicinal plants in different ailments. Charak Samhita is a complete encyclopedia of ayrvedic science with 8 sthanas (Sutrasthanas, Nidansthanas, vomansthanas, sharirsthanas, indriysthanas, chikitsasthanas, Kalpasthanas and siddhisthanas ) divided into 120 chapters (Bagde et.al., 2013). As per Ayurvedic literature, Lord Brahma was the creator of this divine science who inseminated this knowledge to Daksh Prajapati and Ashwini Kumaras (Bagde et.al. 2013). The description of these medicinal plants is also available in different ancient literature, viz., Veda and Puranas (Dobriyal and Godiyal, 2007). 
According to Qureshi and Ghufran (2005), the herbal medicines play an imperative role in rural areas where locally produced drugs are still being used as household remedies for different ailments. Kamraj (2000) is of the opinion that due to their better cultural recognition, lesser side effects, and also the ethno-medicinal significance, the herbal medicine sector is growing as the mainstay for primary health care in the developing countries.

An analysis of the history of traditional ayurvedic system of treatment among folklore of different Himalayan regions in India, it is known that initially this knowledge was restricted to some vaidyas in the region but with the passage of time it was inseminated to others; specially the credit goes to researchers at various level who ventured in to this knowledge and any how brought it in the form of literature (Aswal and Mehrotra, 1994; Rai and Sharma, 1994; Samant, et.al., 1998; Sharma, 2004; Kala, 2006; Shah et.al., 2009; Bhatt et.al., 2010; Dangwal et.al., 2010; Tiwari, et.al., 2010; Kumari et.al., 2012; Sharma, 2013; Prakash, 2014; Bhatia et.al., 2014; Singh and Attri 2014 and Baluni, 2015, 2020). This contribution is also an attempt by the authors to gather information from rural folk of Jaiharikhal block in District Pauri Garhwal and to present it before scientific community. The information was collected using combined approach of observation, discussion with common habitants and experts, and was further checked for an accuracy using the available literature. A total of 46 Wild-Edible medicinal plants were noted belonging to 34 families and 41 genus. Different plant parts, such as wood oil, resin, latex, roots, root bark, tubers, Rhizomes, stems, bark, leaves, flowers, seeds, hairs on pods, Bulb, fruiting body, fruits and whole plant etc were used by the native communities for the treatment of various ailments.

\section{Materials and methods}

Study Area: The present study was based on field survey conducted in 2020-21 in Jaiharikhal Block district Pauri Garhwal to gather information about traditional knowledge of folklore on wild medicinal plants and how they use it in their daily life. Information was collected with the help of questionnaire and discussions with sub urban people, rural folk, farmers and local herbal healers (Vaidyas). Plant Specimens of medicinal values were collected and confirmed about their ethnobotanical usage by consulting relevant literature. Periodic field trips were made during the flowering and fruiting season. All the plant specimens are dried, pressed and identified properly with the help of available literature, monographs (Gaur, 1999).

\section{Results and Discussion}

During present field observation and gathered information through questionnaire, it was concluded that 46 Wild-Edible medicinal plants are in use by the folklore in Jaiharikhal Block of Pauri-District (Table-1). The species fall under 34 families and 41 genus and represent diverse life forms, i.e., climber 04 species, herbs 16 species, shrubs 06 species and trees 20 species. Different plant parts, such as wood oil, resin, latex, roots, root bark, tubers, Rhizomes, stems, bark, leaves, flowers, seeds, Bulb fruiting body, fruits and whole plant etc were used by the native communities for the treatment of ailments. Most of the time local healers (Elderly men or women) used fresh material for medicinal formulations. 
Table-1: Different Wild-Edible medicinal plants used by local communities of Jaiharikhal block from district - Pauri Garhwal.

\begin{tabular}{|c|c|c|c|c|c|}
\hline$\overline{\text { S.No }}$ & Botanical Name & Family & Habit & Local Name & Part used \\
\hline 1 & Argyrcia nervosa (Burm.f.) & Convolvulaceae & Climber & Vriddadaru & Whole plant \\
\hline 2 & Mucuna pruriens (L.) DC. & Fabaceae & Climber & Kauch & Roots and hairs on pods \\
\hline 3 & $\begin{array}{l}\text { Tinospora cardifolia (Willd.) } \\
\text { Hook Fr }\end{array}$ & Menispermaceae & Climber & Giloy & Stem \\
\hline 4 & Rubia cordifolia $\mathrm{L}$. & Rubiaceae & Climber & Majethi & Roots \\
\hline 5 & Allium sativum $\mathrm{L}$ & Alliaceae & Herb & Lasuna & Bulb \\
\hline 6 & Centella asiatica (L.) Urban & Apiaceae & Herb & Brahmi & Whole plant \\
\hline 7 & Cuminum cyminum $\mathrm{L}$. & Apiaceae & Herb & Zeera & Fruit \\
\hline 8 & Coriandrum sativum $\mathrm{L}$ & Apiaceae & Herb & Dhaniya & Fruit \\
\hline 9 & Tagetes minuta $\mathrm{L}$. & Asteraceae & Herb & $\begin{array}{l}\text { Jangali } \\
\text { genda }\end{array}$ & Flowering tops \\
\hline 10 & Vernonia cinerea $(\mathrm{L})$ Less & Asteraceae & Herb & Kalijiri & Leaf, flower and seed \\
\hline 11 & Dioscorea bulbifera L. & Dioscoreaceae & Herb & Genthi & Roots \\
\hline 12 & Trigonella foenumgraecum $\mathrm{L}$ & Fabaceae & Herb & Methi & Seed and fruit \\
\hline 13 & Glycyrrhiza glabra L. & Fabaceae & Herb & Muleti & Stem and root \\
\hline 14 & Ocimum sanctum $\mathrm{L}$. & Lamiaceae & Herb & Tulsi & Whole plant \\
\hline 15 & Mentha arvensis $\mathrm{L}$. & Mimosaceae & Herb & Pudina & Leaf \\
\hline 16 & $\begin{array}{l}\text { Bergenia ligulata (wall) } \\
\text { Engle. }\end{array}$ & Saxifragaceae & Herb & Silpara & Rhizomes \\
\hline 17 & Datura stramonium L. & Solanaceae & Herb & Dhatura & $\begin{array}{l}\text { Leaves, flowering tops } \\
\text { and seeds }\end{array}$ \\
\hline 18 & Valeriana jatamansi Jones. & Valeriancaceae & Herb & Sumaya & Rhizomes and rootlets \\
\hline 19 & $\begin{array}{l}\text { Elettaria cardamomum } \\
\text { Maton }\end{array}$ & Zingiberaceae & Herb & Elaechi & Seed \\
\hline 20 & $\begin{array}{l}\text { Hedychium spicatum } \\
\text { Ham.ex smith }\end{array}$ & Zingiberaceae & Herb & Banhaldi & Rhizomes \\
\hline 21 & Nerium odorum Blanc & Apocynaceae & Shrub & Kaner & Leaf and root \\
\hline 22 & Berberis aristata (D.C.) & Berberidaceae & Shrub & Kingore & Roots, root bark, stem \\
\hline 23 & Ricinus communis $\mathrm{L}$. & Euphorbiaceae & Shurb & Arandi & $\begin{array}{l}\text { Roots, root bark, leaves } \\
\text { and seeds }\end{array}$ \\
\hline 24 & Hibiscus rosa-sinesis L. & Malvaceae & Shrub & Gudehal & Fruit \\
\hline 25 & Punica granatum L. & Punicaceae & Shurb & Dalyma & Fruits \\
\hline 26 & $\begin{array}{l}\text { Withania somnifera (L) } \\
\text { Dunal }\end{array}$ & Solanaceae & Shurb & Aswagandha & Roots \\
\hline 27 & Mangifera indica $\mathrm{L}$. & Acanthaceae & Tree & Aam & seeds and bark \\
\hline 28 & Cassia fistula $\mathrm{L}$. & Caesalpiniaceae & Tree & Amaltas & Fruits and roots \\
\hline 29 & Saraca asoca (Roxb.) & Caesalpiniaceae & Tree & Ashoka & Bark and leaf \\
\hline 30 & $\begin{array}{l}\text { Terminalia arjuna (roxb) ex. } \\
\text { DC }\end{array}$ & Combretaceae & Tree & Arjuna & Bark \\
\hline 31 & Terminalia & Combretaceae & Tree & Bahera & Fruits \\
\hline
\end{tabular}


(Gaerth.) Roxb.

32 Terminalia chebula (Gertn.) Combretaceae Retx

33 Emblica officinalis Gaertn.

34 Juglans regia L.

Euphorbiaceae

Juglandaceae

35 Cinnamomum tamala (Ham.) Lauraceae Nees ex.Eberm.

36 Cinnamomum zeylanicum Lauraceae Nees

37 Melia azedarach L.

38 Ficus carica $\mathrm{L}$.

Meliaceae

Moraceae

39 Ficus glomerata Roxb., Pl. Moraceae Corom

40 Ficus benghalensis (Linn) Moraceae

41 Myrica esculenta Ham. Myricaceae Ex.D.Dun

42 Eugenia jambolana. Lam Myrtaceae

43 Cedrus deodara (Royale Pinaceae ex.D.Don)

44 Pinus roxburghii Sarg Pinaceae

45 Sapindus mukorossi Gaertn Sapindaceae

46 Taxus baccata auct. (Non L.) Taxaceae

Formulations are in the form of fresh juice (swarasa), paste (lepa), decoction with boiled water (kwatha), powder (churna), ghrita \& taila (oil), kasaya (decoction) and paka (semi solid preparation with ghee or oil). Specific use and SOP of particular herb in a particular disease is not mentioned here as it is already available in literature elsewhere (Negi, 1994; Bahuguna, et.al., 2006)

The inhabitants of rural areas are largely dependent on medicinal plants for curing various ailments (Samant et al. 2007). But due to overexploitation and habitat degradation, the population of most of the economically important species is decreasing fast (Samant et al. op cit). One other reason of diminishing traditional knowledge of medicinal plants is the sole dependence on allopathic mode of treatment. Though significant work has been conducted on
Tree Harad Fruits

Tree Amla Fruit

Tree Akhrot Leaves, stem bark, and fruits

Tree Tejpatta Leaves and Bark

Tree Dalchini Bark

Tree Daikan Leaves, barks and fruits

Tree Fig Fruit and latex

Tree Gular Fruit, Bark and roots

Tree Bargad Fruits, barks and leaves

Tree Kaphal Barks and fruits

Tree Jamun Bark and seed

Tree Devdara Wood oil and bark

Tree Chir Bark and resin

Tree Ritha Fruits

Tree Thuner Leaves and bark traditional use of medicinal plants around different parts of Himalaya (In Pakistan by Qureshi \& Ghufran, 2005; in western Nepal by Singh and Hamal, 2013; in Himachal Pradesh by Aswal \& Mehrotra,1994; in Sikkim Hills by Rai and Sharma, 1994; in Jammu and Kashmir by Bhatia et. al, 2014; in Darjeeling Hills by Sharma, 2013; and in Uttarakhand by Singh \& Attri, 2014; Baluni, 2015, 2020, etc.), yet majority of urban and semi urban population believes more on allopathic system of treatment, might be due the reason that at Government level, the ayurvedic system of treatment could not get more attention. It is desirable to give priority to culture these medicinal herbs in large scale by using even biotechnological tools.

The inhabitants of Uttarakhand are still considerably dependent on traditional vaidyas (practitioners of Ayurveda) and local healers for 
treating diseases (Kala 2000, 2005a). Specialists are people for whom medicinal and aromatic plants are major components of their livelihood, such as trained practitioners (vaidyas, Ayurvedic doctors, pharmacists), folk knowledge based vaidyas, dai (women practitioners), and other traditional health practitioners. There are quite a few people who used medicinal plants as a home remedy merely on the basis of past experiences. However, recent years have witnessed fragmentation and outright loss of the traditional plant knowledge. This is high time to conserve and inseminate this very important knowledge and plan a national policy for culture and conservation of these plant species.

\section{Reference}

Aswal B S and Mehrotra B N (1994). Flora of Lahaul-Spiti (a cold desert in north-west Himalayas). Dehradun: Bishen Singh Mahendra Pal Singh.

Bagde AB, Sawant RS, Sawai RV, Muley SK and Dhimdhime RS (2013). Charak- Samhita Complete encyclopedia of Ayurvedic Science. International Journal of Aurveda and Alternative medicine. 1 (1):12-20.

Bahuguna, Prasanna, Badoni PP, Aswal M and Barthwal A.(2006). On the use of herbal medicines in Pauri Garhwal Uttaranchal. $J$. Mountain Res. 1: 155-159.

Baluni P (2015). An insight into the use of rare medicinal plants by the rural folk of Chamoli Garhwal. J. Mountain. Res. 10:21-28.

Baluni P (2020). Ethno-Medical documentation of plants used by the rural folk of Pauri and Kot

Blocks in District Garhwal, Uttarakhand. J. Mountain Res. 15:

Bhatia H, Sharma YP, Manhas RK and Kumar K (2014). Ethnomedical plants Used by the villagers of district Udhampur, J\&K, India. $J$. Enthopharm., 151:1005-1018.
Bhatt A, Baunthiyal M., Pandey, A., Dangwal, H, Singh, A.K. (2010). Ethnobotanical uses of plants for curing diseases and ailments by people of Pauri Garhwal. J. Mountain Res. 5:129-139.

Dangwal L R, Sharma A. and Rana C. S. (2010). Ethno-medicinal plants of the Garhwal Himalaya used to cure vary diseases. A case study. New York Sci. Jl; 3(12): 28-31.

Dobriyal Kusum and Godiyal J.K. (2007). Padm Puran men varnit Aushadhiya padapon ki vartman men chikitskiya Upiyogita Chapter 25- In D R Khanna et.al. Edited: Aushadhiya Padap, Daya Publishing Company (ISBN:817035-492-7) pp 299-304

Gaur R.D.(1999). Flora of District Garhwal: North West Himalaya (with Ethno-botanical Notes).Transmedia publication , Srinagar (Garhwal).

Kala C.P. (2006). Medicinal plants of the high altitude cold desert in India: diversity, distribution and traditional uses. Int. J. Biodiv. Sci. Manag. 2:43-56.

Kumari P., Joshi G.C., Tewari L.M. (2012). Indigenous uses of threatened ethnomedicinal plants used to cure different diseases by ethnic people of Almora district of Western Himalaya. Int. J Ayurvedic Herb. Med. 2(4):661-678.

Negi G.S. (1994). Study of the ancient traditional therapeutic wealth of Pauri and Tehri Garhwal - Part III. \{Pauri Garhwal).HCPB 11.7-17

Prakash, R. (2014). Traditional uses of medicinal plants in Uttarakhand Himalayan Region. Schol. Acd. J Biosci. 2(5): 345-353.

Qureshi R.A and Ghufran M.A (2005). Medicinal value of some important roses and allied species of northern areas of Pakistan. In: Hashmi M, Editor. Pakistan Rose Annual. Aabpara: Pictorial Printers (Pvt.) Ltd.; p.2429. 
Rai L. and Sharma E (1994). Medicinal plants of Sikkim Himalaya: status, usage and potential. Dehradun: Bishen Pal Singh Mahendra Pal singh.

Samant S S, Dhar U and Palni L M S (1998). Medicinal plants of Indian Himalaya: diversity, distribution, potrential values. Nainital: Gyanodaya Prakashan.

Shah N H, Mahmud S and Shamim AA (2009). Plants used against rheumatism by the Gujjar, Bakerwal and pahari tribes of District Poonch (J\&K). Plant Sci.; (11): Pp. 587-588.

Sharma B C (2013). Ethno medicinal plants used against skin diseases by indigenous population of Darjeeling Himalayas, India. Indian J. Fund. Appl.. Life Sci.. 3(3): 299-303.

Sharma R (2004). Agro-Techniques of Medicinal Plants. Dava Publishing House, Delhi, India, 1-2.

Singh A G and Hamal J P (2013). Traditional phytotherapy of some Medicinal plants used by Tharu and Magar communities of western Nepal, Against ermatological disorders. Sci. World. 11(11):81-89.

Singh P and Attri B L (2014) Survey on traditional uses of medicinal plants of Bageshwar valley (Kumaun Himalaya) of Uttarakhand, India. Int. J Cons. Sci.,. 5(2): 223-234.

Tiwari JK, Ballabha R and Tiwari P (2010). Diversity and present status of medicinal plants in and around Srinagar Hydroelectric power project in Garhwal Himalaya, India: Needs Cons. Res., 2(2):50-60. 